\title{
From antibodies to living drugs: Quo vadis cancer immunotherapy?
}

\author{
Árpád Szöőr · János Szöllösi ${ }^{1,2}$ · György Vereb ${ }^{1,2,3}$
}

Received: 22 November 2020 / Accepted: 12 January 2021 / Published online: 1 February 2021

(C) The Author(s) 2021

\begin{abstract}
In the last few decades, monoclonal antibodies targeting various receptors and ligands have shown significant advance in cancer therapy. However, still a great percentage of patients experiences tumor relapse despite persistent antigen expression. Immune cell therapy with adoptively transferred modified T cells that express chimeric antigen receptors (CAR) is an engaging option to improve disease outcome. Designer T cells have been applied with remarkable success in the treatment for acute B cell leukemias, yielding unprecedented antitumor activity and significantly improved overall survival. Relying on the success of CAR T cells in leukemias, solid tumors are now emerging potential targets; however, their complexity represents a significant challenge. In preclinical models, CAR T cells recognized and efficiently killed the wide spectrum of tumor xenografts; however, in human clinical trials, limited antitumor efficacy and serious side effects, including cytokine release syndrome, have emerged as potential limitations. The next decade will be an exciting time to further optimize this novel cellular therapeutics to improve effector functions and, at the same time, keep adverse events in check. Moreover, we need to establish whether gene-modified $\mathrm{T}$ cells which are yet exclusively used for cancer patients could also be successful in the treatment for other diseases. Here, we provide a concise overview about the transition from monoclonal antibodies to the generation of chimeric antigen receptor T cells. We summarize lessons learned from preclinical models, including our own HER2-positive tumor models, as well as from clinical trials worldwide. We also discuss the challenges we are facing today and outline future prospects.
\end{abstract}

Key words Immunotherapy · Cell therapy · Humanized antibody · Bispecific antibody $\cdot$ Chimeric antigen receptor . Chimeric autoantibody receptor

\section{Abbreviations}

ADC Antibody-drug conjugate

ADCC Antibody-dependent cell-mediated cytotoxicity

AML Acute myelomonocytic leukemia

B-ALL Acute B cell lymphocytic leukemia

B-CLL Chronic B cell lymphocytic leukemia

BCM Baylor College of Medicine

BiTE Bispecific T cell engager

György Vereb

gvereb2020@gmail.com

1 Department of Biophysics and Cell Biology, Faculty of Medicine, University of Debrecen, Egyetem tér 1., 4032 Debrecen, Hungary

2 MTA-DE Cell Biology and Signaling Research Group, Faculty of Medicine, University of Debrecen, Egyetem tér 1., 4032 Debrecen, Hungary

3 Faculty of Pharmacy, University of Debrecen, Egyetem tér 1., 4032 Debrecen, Hungary
CAR Chimeric antigen receptor

CAAR Chimeric autoantibody receptor

CR Complete remission

CRS Cytokine release syndrome

CTLA4 Cytotoxic T lymphocyte associated protein 4

DLBCL Diffuse large B cell lymphoma

ECM Extracellular matrix

EGFR Epidermal growth factor receptor

EGFRvIII Epidermal growth factor receptor variant 3

EMA European Medicines Agency

EPIC Evaluation of 7E3 for the prevention of ischemic complications

FceRI $\gamma$ High-affinity immunoglobulin-E receptor gamma chain

FDA US Food and Drug Administration

HER2 Human epidermal growth factor receptor 2

IgG Human immunoglobulin $\mathrm{G}$

$\mathrm{mAb} / \mathrm{s} \quad$ Monoclonal antibody/ies

MHC Major histocompatibility complex

MSKCC Memorial Sloan Kettering Cancer Center 


$\begin{array}{ll}\text { NCI } & \text { National Cancer Institute } \\ \text { NK } & \text { Natural killer } \\ \text { PD1 } & \text { Programmed cell death protein 1 } \\ \text { PDL-1 } & \text { Ligand of programmed cell death protein 1 } \\ \text { PR } & \text { Partial response } \\ \text { scFv } & \text { Single-chain variable fragment } \\ \text { SD } & \text { Stable disease } \\ \text { TAA } & \text { Tumor associated antigen } \\ \text { TCR } & \text { T cell receptor complex } \\ \text { TIL } & \text { Tumor-infiltrating lymphocyte } \\ \text { TME } & \text { Tumor microenvironment } \\ \text { TRUCK } & \text { T cells redirected for universal cytokine- } \\ & \text { mediated killing }\end{array}$

\section{Monoclonal antibodies in cancer therapy: potentials and limitations}

Since the first use of monoclonal antibodies (mAbs) in a lymphoma patient in 1980 (Nadler et al. 1980), these molecules have made a striking transformation from scientific tools to potent drugs in clinical care. In the last three decades, more than 90 monoclonal antibodies have been approved by the European Medicines Agency (EMA) and the US Food and Drug Administration (FDA) as biotherapeutics (Moorkens et al. 2020) (https://www.antibodysociety.org/resources/ approved-antibodies/) and translated from research to bedside. The increasing importance of therapeutic mAbs is apparent, as they have become first-line treatment modalities in immunologic diseases (Steinman 1990) and, in particular, in cancer therapy (Friedlander et al. 2008; Tsumoto et al. 2019). Since the approval of the first clinically used antibody (muromonab, targeting CD3 for preventing allograft rejection (Cosimi 1987)), their number is constantly growing (Fig. 1). Table 1 summarizes the historical landmarks of the ever expanding realm of therapeutic mAbs, from conception through various approaches of adapting them to the human immune system to groundbreaking new concepts in both structural design and clinically important targets.

The most frequently occurring antibody molecules, including IgG-s, are Y-shaped molecules made up of dimers of three roughly equal-sized domains, connected by flexible linkers. Fab fragments representing the bifurcating arm of the $\mathrm{Y}$ are involved in antigen binding. They are comprised of a constant and a variable region. The segment actually binding the target epitope of the antigen, called the paratope, is located within the latter. Fc fragment representing the stem of the Y interacts with effector cells. Since most parts of the antibody have a subtype- and species-specific amino acid sequence, the molecule itself can become and antigen in another species. Therefore, exploitation of antibodies in human therapy has evolved from using the original mouse monoclonals through transferring the variable region to a corresponding human antibody (chimeric $\mathrm{Ab}$ ) to replacing only the paratope in the human antibody (humanized $\mathrm{Ab}$ ), and, eventually, to creating fully human antibodies.

The molecular structure of mAbs determines their effector function exerted on the target antigen. They can directly
Fig. 1 Milestones in monoclonal antibody development. Timeline from 1986 showing the development of therapeutic antibodies. The circles with the numbers represent the number of FDA approved antibodies in each indicated year. Molecules highlighted with gray represent the antibody drugs that have proved to be a milestone in clinical practice

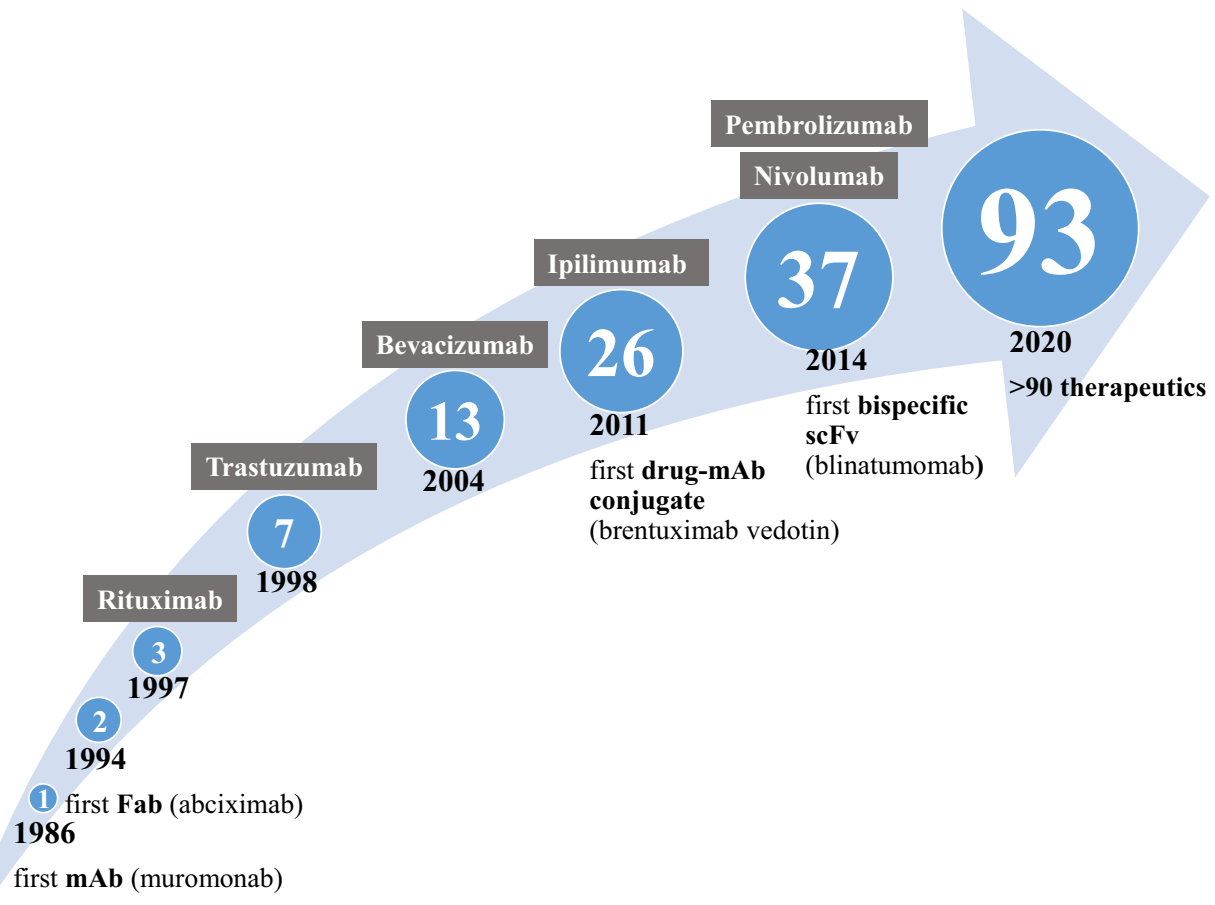


Table 1 Historical landmarks in developing therapeutic mAbs

\begin{tabular}{|c|c|c|c|c|c|}
\hline $\begin{array}{l}\text { International non-proprietary } \\
\text { name, US product identifier }\end{array}$ & Brand name & Target; Format & $\begin{array}{l}\text { Indication first approved or } \\
\text { reviewed }\end{array}$ & $\begin{array}{l}\text { First EU } \\
\text { approval } \\
\text { year }\end{array}$ & $\begin{array}{l}\text { First US } \\
\text { approval } \\
\text { year }\end{array}$ \\
\hline Muromonab-CD3 & Orthoclone Okt3 & CD3; Murine IgG2a & $\begin{array}{l}\text { Reversal of kidney transplant } \\
\text { rejection }\end{array}$ & 1986 & 1986 \\
\hline Abciximab & Reopro & GPHb/IIIa; Chimeric IgGl Fab & $\begin{array}{l}\text { Prevention of blood clots in } \\
\text { angioplasty }\end{array}$ & 1995 & 1994 \\
\hline Rituximab & MabThera, Rituxan & CD20; Chimeric IgGl & Non-Hodgkin lymphoma & 1998 & 1997 \\
\hline Trastuzumab & Herceptin & HER2; Humanized IgGl & Breast cancer & 2000 & 1998 \\
\hline Bevacizumab & Avastin & VEGF; Humanized IgGl & Colorectal cancer & 2005 & 2004 \\
\hline Ipilimumab & Yervoy & CTLA-4; Human IgGl & Metastatic melanoma & 2011 & 2011 \\
\hline Brentuximab vedotin & Adcetris & CD30; Chimeric IgGl; ADC & $\begin{array}{l}\text { Hodgkin lymphoma, systemic } \\
\text { anaplastic large cell lymphoma }\end{array}$ & 2012 & 2011 \\
\hline Blinatumomab & Blincyto & $\begin{array}{l}\text { CD 19, CD3; Murine bispe- } \\
\text { cific tandem scFv }\end{array}$ & Acute lymphoblastic leukemia & 2015 & 2014 \\
\hline Nivolumab & Opdivo & PD1; Human IgG4 & $\begin{array}{l}\text { Melanoma, non-small cell lung } \\
\text { cancer }\end{array}$ & 2015 & 2014 \\
\hline Pembrolizumab & Keytruda & PD1; Humanized IgG4 & Melanoma & 2015 & 2014 \\
\hline
\end{tabular}

induce apoptosis by tuning mitogen-dependent signaling pathways upon interacting with transmembrane receptors resulting in their downregulation, or by interrupting their interactions with adjacent signaling partners (Cuello et al. 2001). When receptor blocking is the sole desired effect, often the Fab fragment proves to be the optimal solution, such as in the case of abciximab, which targets gpIIb/IIIa thereby decreasing platelet aggregation (EPIC 1994). Notably, this is not only the first Fab approved for clinical use, but efforts have been made to decrease its immunogenicity; it is a chimeric antibody, with human IgG1 forming the constant region, and only the variable region preserved from the original mouse IgG (Nesic et al. 2020).

IgG1 and IgG3 subtypes can induce cytotoxic immune cells (monocytes, macrophages, NK cells and granulocytes) expressing Fc receptors to evoke antibody-dependent cellular cytotoxicity (Barok et al. 2008, 2007; Nagy et al. 2005; Perlmann et al. 1975). The same subsets of mAbs are also able to activate the complement cascade to induce indirect cytotoxicity (Meyer et al. 2014). These effector mechanisms make monoclonal antibodies ideal for the targeted therapy of various malignancies. Rituximab, targeting CD20 on lymphoma cells, was the first to be approved for such purpose, and even though a decade has passed since the approval of the first therapeutic antibody, it was still the third on the list of approved ones. Similarly to abciximab (the second antibody on the list), rituximab is also a chimeric, mouse/ human antibody.

From here, progress was boosted, and soon the first antibody (trastuzumab) targeting HER2 on solid tumors was approved (Baselga et al. 1998). This antibody was humanized and contains only the antigen-binding loops from the original mouse Ab4D5, complemented with human variable region framework residues plus the $\mathrm{IgG} 1$ constant domains (Carter et al. 1992). As an extension of the concept, a couple of years later the tumor stroma has also become the target of humanized antibody therapy, first using bevacizumab to neutralize VEGF and thereby inhibit tumor angiogenesis (Bergsland and Dickler 2004).

The next development, in terms of both structure and concept, was to use antibodies to deliver toxins or classic chemotherapeutic agents to tumor cells. The first such ADC (antibody-drug conjugate) approved for clinical use was brentuximab vedotin binding to CD30 on Reed-Sternberg cells in Hodgkin lymphoma (Younes et al. 2010). Not surprisingly, the pioneering mAb in the therapy of solid tumors, trastuzumab, has followed suit, in the form of a maytansinoid conjugate (Barok et al. 2018; Le Joncour et al. 2019; Mathew and Perez 2011).

The ability to easily generate chimeric and humanized antibodies has opened further perspectives in that chimeric multiparatopic antibodies have been created and tested preclinically. The first of these to make it to clinical approval was blinatumomab, a bispecific $\mathrm{T}$ cell engager (BiTE) (Loffler et al. 2000). This new class of synthetic antibodyderived immunotherapeutic molecules has been designed to redirect $\mathrm{T}$ cells to tumor cells by simultaneously targeting two antigens, one on tumor cells (in this case CD19 on B-ALL cells) and the other one-conveniently CD3-on T cells (Huehls et al. 2015).

In terms of expanding the scope of molecular targets, the development of $\mathrm{T}$ cell-targeted immunomodulators blocking the immune checkpoints has revolutionized cancer therapy in the last decade (Hui 2019). In 2011, FDA 
approved ipilimumab as the first $\mathrm{mAb}$-based immune checkpoint inhibitor targeting CTLA4 (Cameron et al. 2011; Hodi et al. 2010). This was followed by the development of other monoclonal antibodies targeting PD1 (pembrolizumab and nivolumab) and PD-L1 (atezolizumab and durvalumab) (Robert et al. 2014). Recently, anti-PD1/PD-L1 monoclonal antibodies have become the most generally administered anticancer therapies in the USA. These molecules are used as monotherapy or in combination with chemo- or radiotherapy against more than 70 cancer types (Tang et al. 2018).

Despite the success of mAbs, we still have a great percentage of cancer patients with limited responses due to preexisting or acquired therapy resistance. Many mechanisms have already been identified including obstacles for mAbs binding to their target antigen (tumor microenvironment (TME)/extracellular matrix(ECM) or downregulation of the target) (Carraway et al. 2001; Friedlander et al. 2005; Nagy et al. 2005), induction of resistance by activating alternative signaling pathways in the tumor (Chan et al. 2005; Friedlander et al. 2008; Wang et al. 2013) and immunomodulatory effects of the tumor cells themselves (Scaltriti et al. 2009) or the tumor microenvironment (TME) via checkpoint activators, exosomes and microvesicles (Derakhshani et al. 2020).

In the last decade, our group has systemically explored key resistance mechanisms limiting the action of the often administered HER2-specific monoclonal antibody, trastuzumab. We have shown that overexpression of extracellular matrix (ECM) components such as MUC4 or CD44/hyaluronan plays a crucial role in the suppression of effector function by forming a steric barrier that masks the HER2 antigen and inhibits its recognition by therapeutic mAbs. We confirmed using in vitro (Nagy et al. 2005), in vivo (Barok et al. 2008, 2007; Palyi-Krekk et al. 2007, 2008; Szoor et al. 2020) and clinical (Varadi et al. 2012) models that epitope masking of HER2 is emphatic in later stage or advanced tumors with massive extracellular matrix and restricts access to antigens. However, trastuzumab can still bind to early-stage tumors as well as to circulating and disseminated tumor cells and induce antibody-dependent cellular cytotoxicity (ADCC) (Barok et al. 2008, 2007). In addition, targeting multiple epitopes by combined treatment with pertuzumab and trastuzumab further improves ADCC and recruits higher number of effector cells, thereby delaying tumor outgrowth (Toth et al. 2016). These results suggest that in spite of intrinsic biological resistance of tumor cells, ADCC by cytotoxic cells can potentially overcome primary resistance and hinder tumor outgrowth while the extracellular matrix is underdeveloped.

These findings encouraged us to move on and design a cytotoxic $\mathrm{T}$ cell that expresses trastuzumab as an extracellular recognition tool. This genetically engineered molecule is known as chimeric antigen receptor (CAR). Our recent data indicate that $\mathrm{CAR}$ wielding $\mathrm{T}$ cells in contrast to antibodies can be efficacious against antibody-resistant tumors providing a significant survival advantage (Szoor et al. 2020; Toth et al. 2020).

\section{Immune cell therapy: promising novel approach to treat cancer}

Development of various biological and immunotherapies is regarded as a paramount achievement of the past decade in cancer therapy. The ultimate goal is to design effective, targeted treatments that put less strain on the patient, but, at the same time, can be administered against a broad range of tumors.

A major breakthrough in the development of such targeted treatments was the emergence of adoptive immune cell therapy. As early as the early 1980s, Steven A. Rosenberg with his team began using autologous $\mathrm{T}$ lymphocytes to treat a large variety of tumors that occurred in various organs (so-called solid tumors). In their pioneering trial, $\mathrm{T}$ cells were isolated from peripheral blood mononuclear cells of cancer patients and then activated and expanded with a megadose of IL-2 cytokine stimulus (Dudley and Rosenberg 2003). Over the next decade, multiple clinical trials were initiated to treat advanced cancer patients with adoptively transferred $\mathrm{T}$ cells that were initially obtained from peripheral blood and then later from tumor tissue (tumorinfiltrating lymphocyte-TIL) (Rosenberg et al. 2008). Out of the various tumors treated, consistent promising results only came when patients with melanoma (a malignant skin tumor) were treated; more than $40 \%$ of patients responded to the therapy and a significant proportion (about 15\%) was even definitively cured. However, in other solid tumors, no real breakthrough occurred, and in many cases no therapeutic response was observed at all (Rosenberg 2014).

The moderate success of adoptive $\mathrm{T}$ cell immunotherapy has prompted researchers to tweak the approach, resulting in the first genetically modified T cells in the early 1990s (Clay et al. 1999; Eshhar et al. 1993; Gross et al. 1989a, 1989b). These cells were able to specifically recognize and kill various tumor cell lines by binding to their specific tumorassociated antigens (TAA). The successful preclinical trials using such genetically modified $\mathrm{T}$ cells brought the promise of ultra-selective and tumor-specific treatment protocols that can be tailored to the individual needs of patients. The novel technology successfully combined adoptive immunotherapy with new-generation gene editing based on retro- and lentiviral transduction systems that facilitate the specific redirection of $\mathrm{T}$ cell against the targeted tumor.

One of the main groups of the gene-modified immune cells expresses tumor-associated antigen-specific alpha and beta subunits of the T cell receptor complex (TCR $\alpha$ and $\beta$ ). Under physiological conditions, these molecules play a 
crucial role in the specific recognition of peptide antigens presented by cells, be they derived from viruses, or alterations of the cell's own proteome. Today's biotechnology has the potential to design and encode in DNA tumor-neoantigen specific TCR $\alpha$ and $\beta$ molecules in an infinite variety and incorporate these recognition tools into the $\mathrm{T}$ cell membrane (Govers et al. 2014; Johnson et al. 2009; Roszik et al. 2011). Since TCR function is restricted to MHC-presented peptides, the applicability of designer $\mathrm{T}$ cells transduced with specific TCRs is rather restricted, and, similarly to adoptive transfer of tumor-infiltrating lymphocytes, they show significant efficacy in the case of tumors stably presenting TAA peptides, particularly melanomas (Debets et al. 2016). To date, TCR-redirected T cells have progressed to earlyphase clinical trials (Tawara et al. 2017; Tendeiro Rego et al. 2019), but have yet to mature to clinical approval. We would like to hereby recommend an excellent review published very recently on the clinical trials using transgenic TCRs (Oppermans et al. 2020).

Chimeric antigen receptors (CARs) represent the other main group in the field of designer T cells. CARs are chimeric molecules that express an extracellular single-chain variable fragment $(\mathrm{scFv})$ as recognition domain that provides specific and efficient binding to molecular targets (primarily TAAs) and an intracellular TCR zeta (TCR $\zeta$ ) chain that works as an effector domain that is capable of efficient activation of T lymphocytes (Gross et al. 1989a, b) (Fig. 1.). CAR-modified T cells have revolutionized cancer therapy in the past decade. This achievement was recognized by Science magazine in 2013 as "Scientific Breakthrough of the Year" (Couzin-Frankel 2013). Currently, more than two thousand patients receive genetically modified immune cell therapies for a large variety of tumors in more than 500 clinical trials (http://clinicaltrials.gov).

\section{Structure of chimeric antigen receptors}

First-generation chimeric antigen receptors are synthetic molecules that recognize extracellular tumor-associated antigens and simultaneously induce cytotoxic cellular response in T cells (Gross et al. 1989a, b). These CARs (Fig. 2.) only provide the first antigen-dependent signal (signal I) that is essential for T cell activation and target killing.

The extracellular antigen recognition domain is usually a scFv (single-chain variable fragment) containing the variable light (VL) and heavy (VH) chains of the parent monoclonal antibody. This mAb-like behavior of target recognition results in efficient binding of unprocessed extracellular proteins in an MHC-independent manner. Thus, CAR T cells remain effective against target cells that downregulate HLA molecules to avoid immune surveillance (Zhou and Levitsky 2012). Moreover, antibody-like target recognition allows

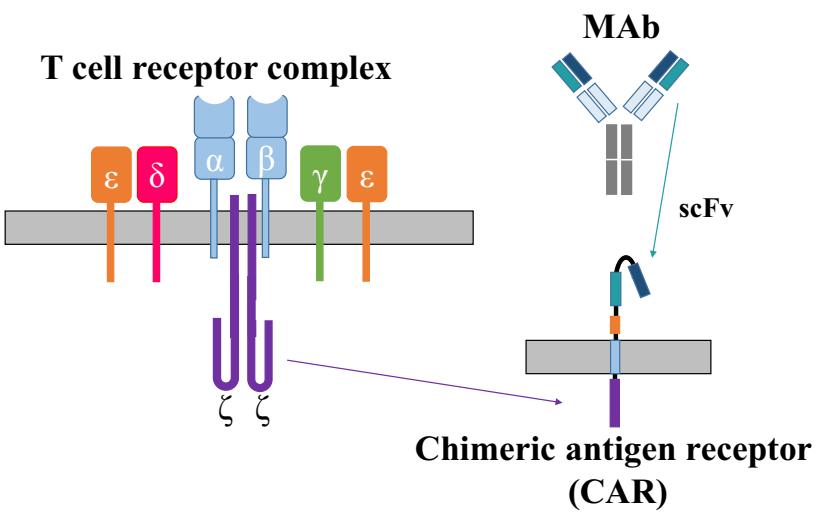

Fig. 2 Schematic structure of a first generation chimeric antigen receptor. The chimeric antigen receptor (CAR) consists of a singlechain variable domain derived from a monoclonal antibody and a sig-

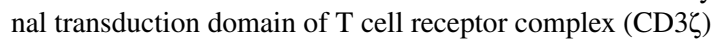

chimeric antigen receptors to bind nonprotein-dominant (carbohydrate or highly glycosylated proteoglycan) tumorspecific antigens ( $\mathrm{Li}$ et al. 2016).

The antigen recognition moiety is connected to the intracellular effector domain by a hinge (also known as linker or spacer) region and its associated transmembrane segment. These two constitute a short, but functionally significant block in the CAR structure. The hinge domain is mostly obtained from $\operatorname{IgG}$ (IgG1 or IgG4) or CD8 (Hombach et al. 2010), while the transmembrane domain usually has a CD4, CD8 or CD28 origin (Bridgeman et al. 2010). The composition and length of the hinge region determine the mobility of the antigen recognition domain as well as the physical distance between the $\mathrm{T}$ cell and the target cell (James et al. 2008).

The transmembrane segment plays a key role in the membrane localization, spontaneous or target-induced dimerization and cluster formation of the CARs (Bridgeman et al. 2010). These factors directly affect the dynamics of intercellular CAR synapse formation and thus influence the cytolytic T cell response (Chmielewski et al. 2004). Furthermore, the transmembrane segment is responsible for forwarding to the cytosolic part of the CAR the conformational change caused by target binding, which explains why sequences from CD4, CD8 or CD28 are used, anticipating similarly effective signal transduction as in the originating proteins.

The intracellular effector (or signaling) domain has crucial role in T cell activation; however, this is the least diverse unit in the CAR backbone. Most commonly, this domain is

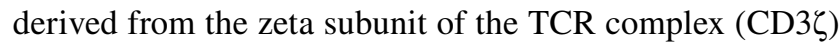
or from the gamma chain of the high-affinity immunoglobulin-E receptor (FceRI $\gamma$ ). Activation of the effector domains initiates phosphatidylinositol and tyrosine kinase-dependent signaling pathways resulting in $\mathrm{T}$ cell activation, proliferation and cytotoxic response (Bridgeman et al. 2014). 
In second- and third-generation CARs (Fig. 3), one or more costimulatory endodomains are incorporated intracellularly, upstream of the signaling domain. These segments, typically derived from CD27, CD28, 4-1BB or OX40 molecules, function as signal enhancers providing costimulatory signals required for complete $\mathrm{T}$ cell activation (signal II) (Zhong et al. 2010). In preclinical trials, costimulatory endodomain-armored CARs induced a more pronounced cytotoxic effect in comparison with first-generation receptors. However, it also appears that distinct costimulatory domains modulate the outcome of effector response in specific ways. For example, signaling from the CD28 cassette initiated by antigen binding suppresses mitochondrial biogenesis. Kawalekar et al. confirmed that in CD28 costimulatory CAR T cells the majority of the energy source is produced by glycolysis, whereas in 4-1BB CAR Ts oxidative phosphorylation in mitochondria dominates (Kawalekar et al. 2016). As a functional consequence, CD28-derived costimulation results in a robust, highly efficient cytotoxic response in which CAR T cells rapidly become exhausted and differentiate into terminal effector memory cells persisting for a shorter time. In contrast, cytotoxic response regulated by the 4-1BB costimulatory endodomain is less intense; however, CAR T cells persist for longer as central memory subsets (Long et al. 2015).

In vitro and in vivo preclinical models suggest that thirdgeneration chimeric antigen receptors containing both types of costimulatory endodomains could further improve the effector functions and the killing potential; however, their translation to clinical use resulted in high therapeutic risk (Morgan et al. 2010).

At present, fourth-generation CAR T cells (TRUCKs, "T cells redirected for universal cytokine-mediated killing") have appeared on the front lines of research. These CAR $\mathrm{T}$ cells are further modified to secrete in the targeted tumor tissue a transgenic cytokine (most commonly IL-7; IL-12 or IL-15), usually under the control of NFkB, upon CAR signaling (Chmielewski and Abken 2015; Chmielewski et al. 2011). Such TRUCKs combine the direct antitumor attack of the CAR T cells with the immune-modulating capacities of the delivered cytokine. Other TRUCKs are engineered to secrete monoclonal antibodies (e.g. PD-1 inhibitor, (Nakajima et al. 2019)), or a bispecific T cell activator molecules (e.g., (Bonifant et al. 2016b; Choi et al. 2019)). These molecules provide an extra signal that leads to "complete $\mathrm{T}$ cell activation" by releasing $\mathrm{T}$ cells from possible checkpoint control by the tumor environment, or recruiting bystander tumor-infiltrating immune cells (Batra et al. 2020).

\section{Genetic modification of T cells with chimeric antigen receptors}

Historically, the first chimeric antigen receptor-modified T cells were generated nonvirally by DNA transfection. The method was advantageous owing to its low immunogenicity and lower probability of mutations; however, the short lifespan of the transfected cells and the rapid drop of CAR expression have manifested as potential limitation (Jensen et al. 2000).

Today, the vast majority of clinical trials and preclinical models use lentiviral (Porter et al. 2011)- or gamma retroviral (Li et al. 2016; Szoor et al. 2020; Toth et al. 2020)-based transduction systems to generate CAR T cells. These methods offer the concept of permanent, efficient and safe modification of primary human $\mathrm{T}$ cells with a plasmid encoding the chimeric receptor. Although lentiviruses could genetically modify quiescent cells as opposed to retroviruses that infect dividing cells, therapeutic effectiveness of different systems is similar (Tang et al. 2016).

The industrial application of viral systems is subject to particularly strict regulations all over the world, so the
Fig. 3 Illustration of the basic structure of four generations of CARs. To improve effector function, second-generation CARs encompass a costimulatory endodomain (e.g., CD28 or 4-1BB) fused to CD3ל. Thirdgeneration CARs consist of two costimulatory domains linked to $\mathrm{CD} 3 \zeta$. In fourth generation CARs, an inducible expression component such as a cytokine (like IL-12), checkpoint inhibitor (anti-PD1) or bispecific T cell engager (anti-CD3-CD19) is engineered into the CAR T cell
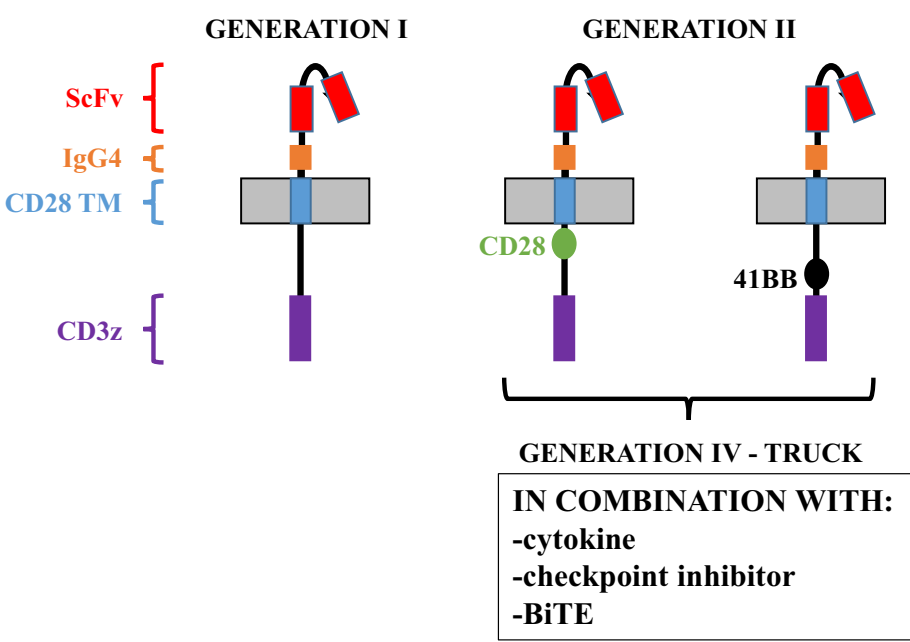

GENERATION III

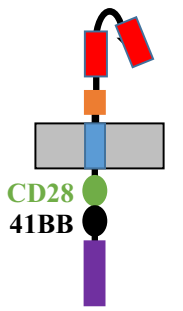


spreading of these methods is slow and CAR T cell manufacturing is expensive. For these reasons, nonviral-based technologies offering cost-effective and long-term stable CAR $\mathrm{T}$ cells are constantly being researched. Sleeping Beauty (SB) (Monjezi et al. 2017) and piggyBac transposonase (Xu et al. 2017) systems were able to produce well-functioning CAR $T$ cells in preclinical models by permanent integration of transgenes; however, clinical efficacy was disappointing (Kebriaei et al. 2016). Alternatively, researchers at the University of Pennsylvania (UPenn) used mRNA electroporation to generate CAR T cells, which does not integrate the transgene into the genome. Their method was stable in midterm range and in clinical trial resulted in transient CAR expression with satisfactory CAR T cell viability. The method was proven as safe; however, insufficient information was published on the therapeutic efficacy (Beatty et al. 2014), and long-term persistence as well as formation of specific memory cells is not achievable with this approach. Researchers at the Fred Hutchinson Cancer Research Center in Seattle published results of a preclinical study in which DNA-carrying nanoparticles successfully modified the genome of circulating peripheral $\mathrm{T}$ cells with chimeric antigen receptors and achieved sustained remission in a leukemia cell line-xenotransplanted mouse model (Smith et al. 2017).

\section{CAR T cells in clinical trials}

\section{Preparation of CART cell products}

CAR $T$ cell therapeutics are usually prepared from the patient's own blood (autologous therapy) in GMP-certified bioreactors. In the first step, mononuclear cells are separated from the blood, and after rapid flow cytometric sorting, $\mathrm{T}$ cells are activated with anti-CD3 (signal I) and anti-CD28 (signal II) human monoclonal antibodies. Cytokines (IL-2 or IL-7 + IL-15) are added to the cell culture at the appropriate concentration to enhance activation (Hollyman et al. 2009). Activated $\mathrm{T}$ cells are then genetically modified with the CAR construct using one of the above-described methods. The quality and the efficacy of CAR transduction are then monitored. If the product meets all strictly regulated release criteria, it will be frozen until use. Prior to administration, patients receive lymphoablative chemotherapy that has been shown to increase the efficacy of CAR T cell therapy in several clinical trials (Maude et al. 2014).

\section{CAR T cells against hematopoietic tumors}

The development of CD19-specific CAR T cells has represented a paradigm shift in the treatment for chemotherapy-refractory acute lymphoblastic leukemias that do not respond to bone marrow transplantation (Porter et al. 2011). A summary focusing on clinical trials completed over the past three years shows that nearly $70 \%$ of this particularly poor-prognosis group achieved complete remission (CR) with therapeutic use of CD19-specific CAR T cells. In addition, the proportion of patients who did not respond to therapy was less than $10 \%$ (Tang et al. 2016). In a clinical trial at UPenn, 27 out of 30 patients (adults and children) responded to anti-CD19 CART treatment with CR (Maude et al. 2014), but a similarly high CR was published by the Memorial Sloan Kettering Cancer Center (MSKCC) (CR: 88\%) (Davila et al. 2014) and by the National Cancer Institute (NCI) (CR: 75\%) (Lee et al. 2015). A deeper analysis of the dataset shows that patients who had received allogeneic bone marrow transplantation several times prior to CAR T cell therapy or whose disease showed extramedullary or neurological involvement had a lower rate of complete remission (CR: 40-50\%). Relapse was more common in these patients with the appearance of CD19-negative (e.g., CD22 or myeloid marker positive) "escape" variants (Haso et al. 2013; Schubert et al. 2020).

Anti-CD19 CAR T cells have also been successfully used in chronic B cell (CD19-positive) lymphocytic leukemia (B-CLL) in US cell therapy centers. In clinical trials at NCI (Kochenderfer et al. 2013), MSKCC (Brentjens et al. 2011), UPenn (Porter et al. 2011), and Baylor College of Medicine (BCM) (Cruz et al. 2013), more than 40 patients were treated with a CD19-specific T cell therapy. Ten patients had CR, ten had PR and five had nonprogressive (stable disease: $\mathrm{SD}$ ) leukemia after treatment.

In lymphoma, clinical trials with first-generation CAR T cells have failed, but recent results with second- and thirdgeneration formulations are encouraging (Lee et al. 2015 118). In the NCI study, 22 patients with refractory diffuse large B cell lymphoma (DLBCL) were treated with antiCD19 CAR T cells following a low-dose conditioning chemotherapy. CR was observed in 14 patients, partial response $(\mathrm{PR})$ in four cases, and SD in one case (Kochenderfer et al. 2017).

In a case report published by UPenn, a patient with multiple myeloma who had previously undergone myeloablative chemotherapy was treated with CD19-specific CAR $\mathrm{T}$ cells. The treatment resulted in a complete therapeutic response with an undetectable tumor at the molecular level. A particularly interest aspect of the case is that CAR T cell therapy was successful despite the fact that only $0.05 \%$ of the patient's plasma cells expressed the CD19 antigen; however, presumably this population represented the least differentiated tumor reservoir that was resistant to conventional therapies (Garfall et al. 2015).

In the last decade, more than ten research groups initiated clinical trials in patients with acute myeloid leukemia. In the first trial designed by Richie et al. (2013), the Lewis Y 
antigen was targeted in a small group of patients. The study has shown a transient decrease in the number of malignant blasts; however, patients relapsed in the medium to long term. Two other promising targets for AML-specific CAR $\mathrm{T}$ cells are CD33 and CD123. Both antigens are expressed on the surface of AML blasts; however, they are also present on normal hematopoietic stem and progenitor cells (HSPC). Wang et al. published a case report in 2015 describing a 41-year-old patient who had a transient response to CD33specific CART cells (Wang et al. 2015). CD123 is another promising marker in AML. In 2015, the City of Hope National Medical Centre in California opened a pioneering CART-123 trial, using a lentivirally transduced second-generation CAR. In their interim dataset, one of the two patients treated with low-dose CAR T cells achieved a morphological leukemia-free state lasting 70 days and two out of the five patients treated with higher dose of CAR T cells achieved a complete remission. In this group, three patients had stable disease. No dose-limiting toxicities were reported, and all treatment-related cytopenias resolved by 12 weeks post treatment (Cummins and Gill 2019).

Thirty-one years after generating the first functional CAR $T$ cells and 15 years after their first clinical trial, the past 3 years represent a major breakthrough in the history of immune-cell based oncotherapy. In 2017, the FDA approved tisagenlecleucel for the treatment for refractory B-ALL in children (O'Leary et al. 2019) and axicabtagene ciloleucel, for adults with refractory diffuse large B cell lymphoma (Neelapu et al. 2017). In 2018, the EMA has also approved tisagenlecleucel for treating refractory B-ALL up to 25 years of age, as well as adult DLBCL (Ali et al. 2020). Most recently, in July 2020, the FDA gave regulatory approval to the third CAR T cell product, brexucabtagene autoleucel for mantle cell lymphoma (Jain et al. 2020). All three products target the CD19 antigen in membrane of tumor cells.

\section{CAR T cells against solid tumors}

Nowadays, less than 100 clinical trials test CAR T cells against solid tumors (clinicaltrials.gov), which is less than a fifth of leukemia-related trials. Research over the past decade has highlighted many obstacles in using designer $\mathrm{T}$ cells in solid tumors. First, for most malignancies, there is no tumor-associated antigen available that would be a highly specific target for CAR T cells. This leads to a so-called on target, off tumor side effect, which can result in severe, irreversible damage to healthy organs. Second, on the tumor side, the effector function of $\mathrm{T}$ cells may be inhibited by various checkpoint molecules, such as CTLA-4 or PD-1 (Hendry et al. 2016). Third, many times, the persistence of genetically modified $\mathrm{T}$ cells is not sufficiently long in solid tumors (Beatty and O'Hara 2016). Despite these obstacles, a number of CAR T cell clinical trials have been initiated worldwide to target solid tumors originating from a wide variety of organs (lung, esophagus, pancreas, stomach, breast, colon, brain and ovary).

The earliest and most frequently studied therapeutic target to date is the human epidermal growth factor receptor type 2 (ErbB2; EGFR2; HER2). HER2 is highly expressed on the surface of breast, lung, stomach, glia and pancreatic tumor cells (Friedlander et al. 2008). Several preclinical animal models have demonstrated that HER2-specific CAR T cells efficiently eradicate tumors expressing the target antigen (Mata et al. 2014; Szoor et al. 2020; Toth et al. 2020). Despite encouraging results, a clinical breakthrough is yet to come. Although several clinical trials have been completed in which patients with HER2-positive osteosarcoma (Ahmed et al. 2015), glioblastoma (Ahmed et al. 2017), rhabdomyosarcoma (Hegde et al. 2020) or breast cancer (Brudno and Kochenderfer 2016) have been treated with CAR T cell therapy, the majority of patients did not respond to treatment. At this point, it is important to highlight that in a clinical trial targeting a HER2-positive metastatic colon carcinoma, an untreatable "cytokine storm" developed in a 39-year-old patient that shortly immediately led to the patient's death. This unfortunate event delayed the authorization of therapy in solid tumors for several years (Morgan et al. 2010).

The second most targeted antigen is mesothelin, a member of the glycoprotein family, which is expressed on the surface of many tumor cells (mesothelioma, lung, stomach, pancreas, esophageal cancer). Its function is unknown in normal tissues; however, it induces the proliferation and invasion of tumor cells, and its expression is an indicator of poor prognosis (Servais et al. 2012). In several preclinical models, mesothelin-specific CAR T cells (meso-CAR T cells) have been shown to be able to eradicate mesothelinpositive tumors (Carpenito et al. 2009). In a clinical study at UPenn, two patients were treated with mRNA-electroporated meso-CAR T cells with limited success (Beatty et al. 2014).

Furthermore, the disialoganglioside (GD2) glycolipid, which is highly expressed on the surface of neuroblastoma, melanoma and osteosarcoma cells could also be an important target. In a BCM clinical trial, 19 patients received GD2-specific CAR T cells and in three patients complete remission was achieved (Louis et al. 2011).

Although clinical results have not yet been published, it is important to mention the EGFRvIII variant oncogene which belongs to the EGFR receptor family. This molecule is not expressed on normal somatic cells, while highly expressed on the surface of certain glioblastoma and head and neck carcinoma cells. In preclinical models, EGFRvIII-specific CAR T cells have been shown to be highly effective (Johnson et al. 2015). This target molecule is currently being tested for therapeutic efficacy in several clinical trials.

The high response rates observed in leukemia patients treated with CD19-specific CAR T cells have emerged 
CAR T cells as the major breakthroughs of cancer immunotherapies in the last years. However, in solid tumors little clinical effect has been reported owing to the strong immunosuppressive environment and the lack of specific tumor antigens. Fortunately, new strategies are arising with the potential to overcome these limitations. The development of safety mechanisms (Duong et al. 2019), T cell activationdependent constructions (Frigault et al. 2015), combinatorial antigen recognition strategies and multiple-targeting CARs (Porter et al. 2020) as well as CARs that target unhealthy (stressed) tissues in general (Breman et al. 2018) will hopefully result in well-tuned CAR T cells that avoid undesired toxicities, yet efficiently eliminate tumors. It is also good to keep in mind that using TCRs replacing, or built into (Walseng et al. 2017), CARs can target intracellular proteins, as these proteins are processed and presented to the TCR recognition motif by MHC molecules, whereas CARs can only target extracellular proteins, which represent only about $1 \%$ of the potential tumor neoantigens.

\section{Toxicity management in CAR T cell therapy}

CAR T cell therapy does not use the same tool case as the classical adjuvant protocols, chemotherapy and radiation therapy since it does not target and attack rapidly dividing cells. Thus, the profile of expressed side effects during treatments is also very different from those experienced in conventional protocols. To the best of our knowledge, the side effects associated with CAR T cell therapies can be divided into two major groups.

"On target, off tumor" toxicity is when a CAR T cell recognizes a tumor-specific antigen on a normal tissue and destroys the cells expressing it. This is an expected side effect of CD19-specific CAR T cells, since the target antigen is not exclusively expressed in the membrane of malignant cells but it is also found on the surface of normal B lymphocytes. In these cases, B cell aplasia is also a marker of therapeutic efficacy. Fortunately, hypo- or agammaglobulinaemia due to $\mathrm{B}$ cell deficiency can be treated well by administration of human intravenous immunoglobulin (Kochenderfer et al. 2013; Porter et al. 2011).

The earlier mentioned "cytokine release syndrome" (CRS) is the second unwanted side effect of CAR T cell therapies. It is caused by the sudden increase in activating cytokines (interferon- $\gamma$, GM-CSF, TNF- $\alpha$, IL- 6 and IL-10) produced by large numbers of activated immune cells, leading to prolonged high fever, low blood pressure, systemic hypoxia and, in rare cases, multiple organ failure. In recent years, several clinical trials have explored the pathogenic role of IL-6 in the development of CRS. The unwanted effect, which was previously fatal, is now well treated with appropriate doses of the IL-6 receptor blocker mAb tocilizumab (Brudno and Kochenderfer 2019). However, it is important to emphasize that CRS is also a marker of the efficacy of CAR T cell therapy, so completely suppressing it should not be a goal (Bonifant et al. 2016a).

Neurotoxicity, or CAR T cell-derived encephalopathy syndrome, is related to the CRS and is the second most frequent life-threatening side effect associated with CAR T cell therapies (Bonifant et al. 2016a). The most frequently reported symptoms are delirium, aphasia, confusion, somnolence, ataxia, tremors, and in advanced case patients, cerebral edema might be developed (Brudno and Kochenderfer 2019). Despite the observed correlation between high-grade CRS and neurotoxicity, the biological background of this potentially lethal effect is still poorly understood, and emerging clinical management schemes need time to be verified (Neelapu et al. 2018; Rivera et al. 2020).

\section{Applicability of designer T cells in other diseases}

The clinical applicability of genetically modified immune cells relies on the specific and efficient elimination of disease-causing cells. This potential, considering the success of CAR T cell-based cancer therapies, has encouraged many researchers to use CAR-modified immune cells in other disease groups, such as autoimmune diseases and infectious diseases.

Misrecognition of normal tissue components by the autoreactive $B$ cells and plasma cells maintains tissue destruction in autoimmune disorders. These B cells can be eliminated with the widespread use of rituximab (a monoclonal antibody) that recognizes the target cell through the membrane-expressed CD20 molecule and activates an antibodymediated cytotoxic response (ADCC) (Schmidt et al. 2006). However, because the CD20 molecule is not only expressed on autoreactive B cell clones, but also designates for elimination the useful population as a side effect of therapy, complete and persistent B cell aplasia develops. This condition can lead to the development of a severe septic condition (van Vollenhoven et al. 2013).

In recent years, two different concepts have been investigated for developing genetically modified immune cells against autoimmune diseases. In one, chimeric autoantibody receptor T cells (CAAR T cells) have the potential to eliminate autoantibody-expressing B cell clones, as demonstrated for the case of the antibody-mediated autoimmune disease pemphigus vulgaris (PV). It was shown that autoantigenbased chimeric immunoreceptors can direct $\mathrm{T}$ cells to kill autoreactive B lymphocytes through the specificity of their B cell receptor (Ellebrecht et al. 2016) (Fig. 4. concept I). In a conceptually different approach, chimeric antigen receptormodified regulatory $\mathrm{T}$ cells (CAR Tregs) have been used to suppress autoimmune response in murine colitis by carcinoembryonic antigen-specific regulatory $\mathrm{T}$ cells (Blat et al. 2014) (Fig. 4. Concept II). 
Fig. 4 Chimeric antigen receptors as solutions beyond cancer. Examples in autoimmune diseases. Concept I represents chimeric autoantibody receptor $\mathrm{T}$ cells (CAAR) that have the potential to recognize and kill autoreactive B cells. Concept II demonstrates CAR Treg-s inducing suppression of effector cell function upon recognition of the autoantigen
CONCEPT I.

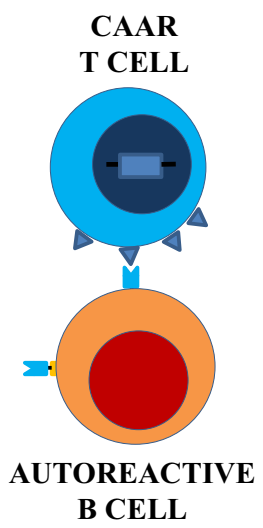

CONCEPT II.

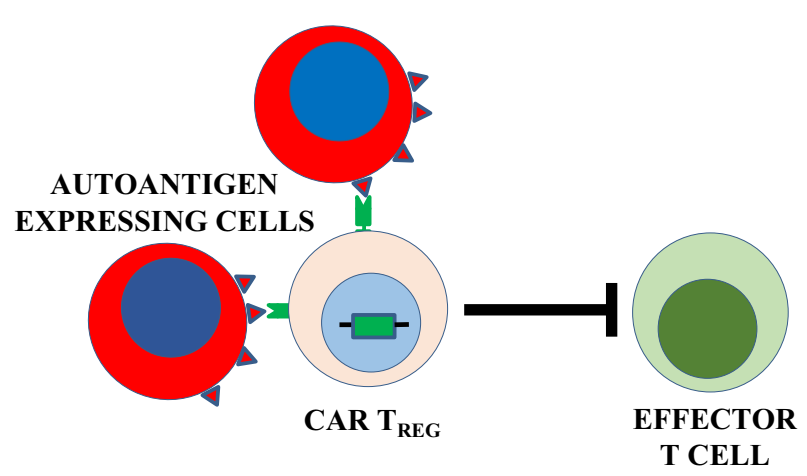

Infectious diseases are the focus of common interest as some of them may present insurmountable problems. In these cases, genetically modified immune cells might have the potential to constitute a breakthrough in the treatment of this rather diverse disease group. Hereinbelow are a few highlights where CAR T cells have been effective against infectious diseases in preclinical studies.

Between 1995 and 2005, several clinical trials were initiated using CD4 CCAR T cells to treat patients with AIDS (Mitsuyasu et al. 2000). These CARs expressed the gp120 binding domains of the CD4 molecule that recognizes the glycoprotein in the membrane of HIVinfected cells. CD4 $\zeta$ CAR T cells were able to detect and eliminate HIV-infected target cells with high efficiency in preclinical models; however, in clinical trials, they failed to exert a sustained antiviral effect. Nowadays, bi- or multispecific CAR T cells are used against HIV. In bispecific CARs, the extracellular CD4 domain is combined with an $\mathrm{scFv}$ that recognizes human $\mathrm{C}$-type lectin that provides access to the viral capsid glycans. This second recognition domain significantly enhanced the specificity of CAR T cells (Ghanem et al. 2018). In a recently published study, CD4/anti C-type kectin CARs were further modified with a gp41-specific $s c F v$ to enhance the efficiency (Anthony-Gonda et al. 2019).

There are some non-HIV viral infections where CAR $\mathrm{T}$ cells have been tested in preclinical trials. Full et al. generated CAR T cells targeting cytomegalovirus (CMV)specific glycoprotein $\mathrm{B}$ in the membrane of infected cells resulting in robust cytokine release (Full et al. 2010). In a recent preclinical study, HBsAg-specific CAR T cells were designed to treat hepatitis $\mathrm{B}$ infection. These CAR $\mathrm{T}$ cells were able to specifically recognize HBV-infected hepatocytes and efficiently lysed virus-replicating cells resulting in reduced plasma HBV-DNA levels (Kruse et al. 2018).

\section{Summary}

During the past four decades, the conceptual evolution of therapeutic antibodies has paved the road from immunosuppressive treatment to various modalities of oncoimmunologic interventions, covering both direct targeting of tumors and immune checkpoint modulation. The next leap forward has been the inclusion of antigen-binding moieties into chimeric antigen receptors (CARs) engineered into designer $\mathrm{T}$ cells, which is currently the most promising, growing branch of clinical oncology. Hundreds of CAR T cell protocols have already reached the clinical trial stage, most of them targeting multiresistant lymphoid tumors. In the past decade, CAR T cells have brought a paradigm shift in the treatment for CD19-positive lymphomas and leukemias. However, for solid tumors clinical results remained limited. In addition, a clinical trial targeting HER2 tumor-specific antigen ended with a fatal cytokine release syndrome (Morgan et al. 2010). This regrettable event draws attention to the need to systematically compare the function and characteristics of the CAR components in terms of activity, efficacy, endurance and long-term survival. In addition, the ability for expansion and the specificity of tumor recognition would also need to be improved.

New fields of application for CAR T cells have also come into view and have reached preclinical stage, including the treatment for autoimmune-diseased and viral infections. With all of this in mind, the next decade has to answer two exciting scientific questions: would genetically modified $\mathrm{T}$ cells become effective alternatives in the treatment for solid tumors, either alone or in combination with checkpoint inhibitors or integrated into cytokine-secreting $\mathrm{T}$ cells (TRUCKs)? On the other hand, do they have enough potential to cover a broader therapeutic palette 
similar to that of monoclonal antibodies, and to be applied in other groups of diseases?

Funding Open Access funding provided by University of Debrecen. We acknowledge the financial support from OTKA K119690 and FK132773 (the National Research, Development and Innovation Office, Hungary) and GINOP-2.3.2-15-2016-00044 (cofinanced by the European Union and the European Regional Development Fund). Á.Sz. was supported by the János Bolyai Research Scholarship of the Hungarian Academy of Sciences and by the UNNK-20-5-DE-48 New National Excellence Program of the Ministry for Innovation and Technology.

Open Access This article is licensed under a Creative Commons Attribution 4.0 International License, which permits use, sharing, adaptation, distribution and reproduction in any medium or format, as long as you give appropriate credit to the original author(s) and the source, provide a link to the Creative Commons licence, and indicate if changes were made. The images or other third party material in this article are included in the article's Creative Commons licence, unless indicated otherwise in a credit line to the material. If material is not included in the article's Creative Commons licence and your intended use is not permitted by statutory regulation or exceeds the permitted use, you will need to obtain permission directly from the copyright holder. To view a copy of this licence, visit http://creativecommons.org/licenses/by/4.0/.

\section{References}

Ahmed $\mathrm{N}$ et al (2017) HER2-specific chimeric antigen receptormodified virus-specific $\mathrm{T}$ cells for progressive glioblastoma: a Phase 1 Dose-Escalation Trial. JAMA Oncol 3:1094-1101. https://doi.org/10.1001/jamaoncol.2017.0184

Ahmed N et al (2015) Human Epidermal Growth Factor Receptor 2 (HER2) -specific chimeric antigen receptor-modified T cells for the immunotherapy of HER2-positive sarcoma. J Clin Oncol 33:1688-1696. https://doi.org/10.1200/JCO.2014.58.0225

Ali S et al (2020) The European Medicines Agency Review of Kymriah (Tisagenlecleucel) for the treatment of acute lymphoblastic leukemia and diffuse large B-Cell lymphoma. Oncologist 25:e321-e327. https://doi.org/10.1634/theoncolog ist.2019-0233

Anthony-Gonda K et al (2019) Multispecific anti-HIV duoCAR-T cells display broad in vitro antiviral activity and potent in vivo elimination of HIV-infected cells in a humanized mouse model. Sci Transl Med. https://doi.org/10.1126/scitranslmed.aav5685

Barok $M$ et al (2008) Trastuzumab decreases the number of circulating and disseminated tumor cells despite trastuzumab resistance of the primary tumor. Cancer Lett 260:198-208. https://doi. org/10.1016/j.canlet.2007.10.043

Barok M et al (2007) Trastuzumab causes antibody-dependent cellular cytotoxicity-mediated growth inhibition of submacroscopic JIMT-1 breast cancer xenografts despite intrinsic drug resistance. Mol Cancer Ther 6:2065-2072. https://doi.org/10.1158/15357163.MCT-06-0766

Barok M, Puhka M, Vereb G, Szollosi J, Isola J, Joensuu H (2018) Cancer-derived exosomes from HER2-positive cancer cells carry trastuzumab-emtansine into cancer cells leading to growth inhibition and caspase activation. BMC Cancer 18:504. https://doi. org/10.1186/s12885-018-4418-2

Baselga J, Norton L, Albanell J, Kim YM, Mendelsohn J (1998) Recombinant humanized anti-HER2 antibody (Herceptin) enhances the antitumor activity of paclitaxel and doxorubicin against HER2/neu overexpressing human breast cancer xenografts. Cancer Res 58:2825-2831

Batra SA et al (2020) Glypican-3-specific CAR T cells coexpressing IL15 and IL21 have superior expansion and antitumor activity against hepatocellular carcinoma cancer. Immunol Res 8:309320. https://doi.org/10.1158/2326-6066.CIR-19-0293

Beatty GL et al (2014) Mesothelin-specific chimeric antigen receptor mRNA-engineered $\mathrm{T}$ cells induce anti-tumor activity in solid malignancies cancer. Immunol Res 2:112-120. https://doi. org/10.1158/2326-6066.CIR-13-0170

Beatty GL, O'Hara M (2016) Chimeric antigen receptor-modified $\mathrm{T}$ cells for the treatment of solid tumors: Defining the challenges and next steps. Pharmacol Ther 166:30-39. https://doi. org/10.1016/j.pharmthera.2016.06.010

Bergsland E, Dickler MN (2004) Maximizing the potential of bevacizumab in cancer treatment. Oncologist 9(Suppl 1):36-42. https ://doi.org/10.1634/theoncologist.9-suppl_1-36

Blat D, Zigmond E, Alteber Z, Waks T, Eshhar Z (2014) Suppression of murine colitis and its associated cancer by carcinoembryonic antigen-specific regulatory T cells. Mol Ther 22:10181028. https://doi.org/10.1038/mt.2014.41

Bonifant CL, Jackson HJ, Brentjens RJ, Curran KJ (2016) Toxicity and management in CAR T-cell therapy. Mol Ther Oncolytics 3:16011. https://doi.org/10.1038/mto.2016.11

Bonifant CL et al (2016) CD123-Engager T cells as a novel immunotherapeutic for acute myeloid leukemia. Mol Ther 24:16151626. https://doi.org/10.1038/mt.2016.116

Breman $\mathrm{E}$ et al (2018) Overcoming target driven fratricide for $\mathrm{T}$ Cell therapy. Front Immunol 9:2940. https://doi.org/10.3389/ fimmu.2018.02940

Brentjens RJ et al (2011) Safety and persistence of adoptively transferred autologous CD19-targeted T cells in patients with relapsed or chemotherapy refractory B-cell leukemias. Blood 118:4817-4828. https://doi.org/10.1182/blood-2011-04-34854 0

Bridgeman JS, Hawkins RE, Bagley S, Blaylock M, Holland M, Gilham DE (2010) The optimal antigen response of chimeric antigen receptors harboring the CD3zeta transmembrane domain is dependent upon incorporation of the receptor into the endogenous TCR/CD3 complex. J Immunol 184:6938-6949. https:// doi.org/10.4049/jimmunol.0901766

Bridgeman JS, Ladell K, Sheard VE, Miners K, Hawkins RE, Price DA, Gilham DE (2014) CD3zeta-based chimeric antigen receptors mediate $\mathrm{T}$ cell activation via cis- and trans-signalling mechanisms: implications for optimization of receptor structure for adoptive cell therapy. Clin Exp Immunol 175:258-267. https:// doi.org/10.1111/cei.12216

Brudno JN, Kochenderfer JN (2016) Toxicities of chimeric antigen receptor T cells: recognition and management. Blood 127:33213330. https://doi.org/10.1182/blood-2016-04-703751

Brudno JN, Kochenderfer JN (2019) Recent advances in CAR T-cell toxicity: mechanisms, manifestations and management. Blood Rev 34:45-55. https://doi.org/10.1016/j.blre.2018.11.002

Cameron F, Whiteside G, Perry C (2011) Ipilimumab: first global approval. Drugs 71:1093-1104. https://doi.org/10.2165/11594 010-000000000-00000

Carpenito C et al (2009) Control of large, established tumor xenografts with genetically retargeted human T cells containing CD28 and CD137 domains. Proc Natl Acad Sci USA 106:3360-3365. https ://doi.org/10.1073/pnas.0813101106

Carraway KL, Price-Schiavi SA, Komatsu M, Jepson S, Perez A, Carraway CA (2001) Muc4/sialomucin complex in the mammary gland and breast cancer. J Mammary Gland Biol Neoplasia 6:323-337. https://doi.org/10.1023/a:1011327708973 
Carter P et al (1992) Humanization of an anti-p185HER2 antibody for human cancer therapy. Proc Natl Acad Sci U S A 89:4285-4289. https://doi.org/10.1073/pnas.89.10.4285

Chan CT, Metz MZ, Kane SE (2005) Differential sensitivities of trastuzumab (Herceptin)-resistant human breast cancer cells to phosphoinositide-3 kinase (PI-3K) and epidermal growth factor receptor (EGFR) kinase inhibitors. Breast Cancer Res Treat 91:187-201. https://doi.org/10.1007/s10549-004-7715-1

Chmielewski M, Abken H (2015) TRUCKs: the fourth generation of CARs. Expert Opin Biol Ther 15:1145-1154. https://doi. org/10.1517/14712598.2015.1046430

Chmielewski M, Hombach A, Heuser C, Adams GP, Abken H (2004) $\mathrm{T}$ cell activation by antibody-like immunoreceptors: increase in affinity of the single-chain fragment domain above threshold does not increase $T$ cell activation against antigen-positive target cells but decreases selectivity. J Immunol 173:7647-7653

Chmielewski M, Kopecky C, Hombach AA, Abken H (2011) IL-12 release by engineered $\mathrm{T}$ cells expressing chimeric antigen receptors can effectively Muster an antigen-independent macrophage response on tumor cells that have shut down tumor antigen expression. Cancer Res 71:5697-5706. https://doi. org/10.1158/0008-5472.CAN-11-0103

Choi BD et al (2019) CAR-T cells secreting BiTEs circumvent antigen escape without detectable toxicity. Nat Biotechnol 37:10491058. https://doi.org/10.1038/s41587-019-0192-1

Clay TM, Custer MC, Sachs J, Hwu P, Rosenberg SA, Nishimura MI (1999) Efficient transfer of a tumor antigen-reactive TCR to human peripheral blood lymphocytes confers anti-tumor reactivity. J Immunol 163:507-513

Cosimi AB (1987) OKT3: First-dose safety and success. Nephron 46(Suppl 1):12-18. https://doi.org/10.1159/000184430

Couzin-Frankel J (2013) Breakthrough of the year 2013. Cancer Immunother Sci 342:1432-1433. https://doi.org/10.1126/scien ce.342.6165.1432

Cruz CR et al (2013) Infusion of donor-derived CD19-redirected virusspecific T cells for B-cell malignancies relapsed after allogeneic stem cell transplant: a phase 1 study. Blood 122:2965-2973. https ://doi.org/10.1182/blood-2013-06-506741

Cuello M et al (2001) Down-regulation of the erbB-2 receptor by trastuzumab (herceptin) enhances tumor necrosis factor-related apoptosis-inducing ligand-mediated apoptosis in breast and ovarian cancer cell lines that overexpress erbB-2. Cancer Res 61:4892-4900

Cummins KD, Gill S (2019) Chimeric antigen receptor T-cell therapy for acute myeloid leukemia: how close to reality? Haematologica 104:1302-1308. https://doi.org/10.3324/haematol.2018.208751

Davila ML et al (2014) Efficacy and toxicity management of 19-28z CAR T cell therapy in B cell acute lymphoblastic leukemia. Sci Transl Med 6:224-225. https://doi.org/10.1126/scitranslm ed.3008226

Debets R, Donnadieu E, Chouaib S, Coukos G (2016) TCR-engineered T cells to treat tumors: Seeing but not touching? Semin Immunol 28:10-21. https://doi.org/10.1016/j.smim.2016.03.002

Derakhshani A et al (2020) Overcoming trastuzumab resistance in HER2-positive breast cancer using combination therapy. J Cell Physiol 235:3142-3156. https://doi.org/10.1002/jcp.29216

Dudley ME, Rosenberg SA (2003) Adoptive-cell-transfer therapy for the treatment of patients with cancer. Nat Rev Cancer 3:666-675. https://doi.org/10.1038/nrc1167

Duong MT et al (2019) Two-dimensional regulation of CAR-T cell therapy with orthogonal switches. Mol Ther Oncolytics 12:124137. https://doi.org/10.1016/j.omto.2018.12.009

Ellebrecht CT et al (2016) Reengineering chimeric antigen receptor $\mathrm{T}$ cells for targeted therapy of autoimmune disease. Science 353:179-184. https://doi.org/10.1126/science.aaf6756
EPIC (1994) Use of a monoclonal antibody directed against the platelet glycoprotein IIb/IIIa receptor in high-risk coronary angioplasty. N Engl J Med 330:956-961. https://doi.org/10.1056/NEJM1 99404073301402

Eshhar Z, Waks T, Gross G, Schindler DG (1993) Specific activation and targeting of cytotoxic lymphocytes through chimeric single chains consisting of antibody-binding domains and the gamma or zeta subunits of the immunoglobulin and T-cell receptors. Proc Natl Acad Sci USA 90:720-724

Friedlander E, Arndt-Jovin DJ, Nagy P, Jovin TM, Szollosi J, Vereb G (2005) Signal transduction of erbB receptors in trastuzumab (Herceptin) sensitive and resistant cell lines: local stimulation using magnetic microspheres as assessed by quantitative digital microscopy. Cytometry A 67:161-171. https://doi.org/10.1002/ cyto.a. 20173

Friedlander E, Barok M, Szollosi J, Vereb G (2008) ErbB-directed immunotherapy: antibodies in current practice and promising new agents. Immunol Lett 116:126-140. https://doi. org/10.1016/j.imlet.2007.12.001

Frigault MJ et al (2015) Identification of chimeric antigen receptors that mediate constitutive or inducible proliferation of $\mathrm{T}$ cells Cancer. Immunol Res 3:356-367. https://doi. org/10.1158/2326-6066.CIR-14-0186

Full F et al (2010) T cells engineered with a cytomegalovirus-specific chimeric immunoreceptor. J Virol 84:4083-4088. https:// doi.org/10.1128/JVI.02117-09

Garfall AL et al (2015) Chimeric antigen Receptor T cells against CD19 for multiple myeloma. N Engl J Med 373:1040-1047. https://doi.org/10.1056/NEJMoa1504542

Ghanem MH et al (2018) Bispecific chimeric antigen receptors targeting the CD4 binding site and high-mannose Glycans of gp120 optimized for anti-human immunodeficiency virus potency and breadth with minimal immunogenicity. Cytotherapy 20:407-419. https://doi.org/10.1016/j.jcyt.2017.11.001

Govers C et al (2014) TCRs genetically linked to CD28 and CD3epsilon do not mispair with endogenous TCR chains and mediate enhanced $\mathrm{T}$ cell persistence and anti-melanoma activity. J Immunol 193:5315-5326. https://doi.org/10.4049/jimmu nol.1302074

Gross G, Gorochov G, Waks T, Eshhar Z (1989a) Generation of effector $\mathrm{T}$ cells expressing chimeric $\mathrm{T}$ cell receptor with antibody type-specificity. Transplant Proc 21:127-130

Gross G, Waks T, Eshhar Z (1989b) Expression of immunoglobulinT-cell receptor chimeric molecules as functional receptors with antibody-type specificity. Proc Natl Acad Sci U S A 86:1002410028. https://doi.org/10.1073/pnas.86.24.10024

Haso W et al (2013) Anti-CD22-chimeric antigen receptors targeting B-cell precursor acute lymphoblastic leukemia. Blood 121:11651174. https://doi.org/10.1182/blood-2012-06-438002

Hegde $M$ et al (2020) Tumor response and endogenous immune reactivity after administration of HER2 CAR T cells in a child with metastatic rhabdomyosarcoma. Nat Commun 11:3549. https:// doi.org/10.1038/s41467-020-17175-8

Hendry SA, Farnsworth RH, Solomon B, Achen MG, Stacker SA, Fox SB (2016) The role of the tumor vasculature in the host immune response: implications for therapeutic strategies targeting the tumor microenvironment. Front Immunol 7:621. https://doi. org/10.3389/fimmu.2016.00621

Hodi FS et al (2010) Improved survival with ipilimumab in patients with metastatic melanoma. N Engl J Med 363:711-723. https:// doi.org/10.1056/NEJMoa1003466

Hollyman D et al (2009) Manufacturing validation of biologically functional T cells targeted to CD19 antigen for autologous adoptive cell therapy. J Immunother 32:169-180. https://doi.org/10.1097/ CJI.0b013e318194a6e8 
Hombach A, Hombach AA, Abken H (2010) Adoptive immunotherapy with genetically engineered T cells: modification of the IgG1 Fc "spacer" domain in the extracellular moiety of chimeric antigen receptors avoids "off-target" activation and unintended initiation of an innate immune response. Gene Ther 17:1206-1213. https ://doi.org/10.1038/gt.2010.91

Huehls AM, Coupet TA, Sentman CL (2015) Bispecific T-cell engagers for cancer immunotherapy. Immunol Cell Biol 93:290-296. https ://doi.org/10.1038/icb.2014.93

Hui E (2019) Immune checkpoint inhibitors. J Cell Biol 218:740-741. https://doi.org/10.1083/jcb.201810035

Jain P et al (2020) Outcomes and management of patients with mantle cell lymphoma after progression on brexucabtagene autoleucel therapy. Br J Haematol. https://doi.org/10.1111/bjh.17197

James SE et al (2008) Antigen sensitivity of CD22-specific chimeric TCR is modulated by target epitope distance from the cell membrane. J Immunol 180:7028-7038. https://doi.org/10.4049/jimmu nol.180.10.7028

Jensen MC et al (2000) Human T lymphocyte genetic modification with naked DNA. Mol Ther 1:49-55. https://doi.org/10.1006/ mthe.1999.0012

Johnson LA et al (2009) Gene therapy with human and mouse T-cell receptors mediates cancer regression and targets normal tissues expressing cognate antigen. Blood 114:535-546. https://doi. org/10.1182/blood-2009-03-211714

Johnson LA et al (2015) Rational development and characterization of humanized anti-EGFR variant III chimeric antigen receptor T cells for glioblastoma. Sci Transl Med 7:275-222. https://doi. org/10.1126/scitranslmed.aaa4963

Kawalekar OU et al (2016) Distinct Signaling of coreceptors regulates specific metabolism pathways and impacts memory development in CAR T cells. Immunity 44:712. https://doi.org/10.1016/j. immuni.2016.02.023

Kebriaei P et al (2016) Phase I trials using Sleeping Beauty to generate CD19-specific CAR T cells. J Clin Investig 126:3363-3376. https ://doi.org/10.1172/JCI86721

Kochenderfer JN et al (2013) Donor-derived CD19-targeted T cells cause regression of malignancy persisting after allogeneic hematopoietic stem cell transplantation. Blood 122:4129-4139. https ://doi.org/10.1182/blood-2013-08-519413

Kochenderfer JN et al (2017) Lymphoma remissions caused by AntiCD19 chimeric antigen receptor $\mathrm{T}$ cells are associated with high serum interleukin-15 levels. J Clin Oncol 35:1803-1813. https ://doi.org/10.1200/JCO.2016.71.3024

Kruse RL et al (2018) HBsAg-redirected T cells exhibit antiviral activity in HBV-infected human liver chimeric mice. Cytotherapy 20:697-705. https://doi.org/10.1016/j.jcyt.2018.02.002

Le Joncour V et al (2019) A Novel Anti-HER2 antibody-drug conjugate XMT-1522 for HER2-positive breast and gastric cancers resistant to trastuzumab emtansine. Mol Cancer Ther 18:1721-1730. https ://doi.org/10.1158/1535-7163.MCT-19-0207

Lee DW et al (2015) T cells expressing CD19 chimeric antigen receptors for acute lymphoblastic leukaemia in children and young adults: a phase 1 dose-escalation trial. Lancet 385:517-528. https ://doi.org/10.1016/S0140-6736(14)61403-3

Li W et al (2016) Redirecting T cells to glypican-3 with 4-1bb zeta chimeric antigen receptors results in Th1 polarization and potent antitumor activity. Hum Gene Ther. https://doi.org/10.1089/ hum.2016.025

Loffler A et al (2000) A recombinant bispecific single-chain antibody, CD19 x CD3, induces rapid and high lymphoma-directed cytotoxicity by unstimulated T lymphocytes. Blood 95:2098-2103

Long AH et al (2015) 4-1BB costimulation ameliorates T cell exhaustion induced by tonic signaling of chimeric antigen receptors. Nature Med 21:581-590. https://doi.org/10.1038/nm.3838
Louis CU et al (2011) Antitumor activity and long-term fate of chimeric antigen receptor-positive $\mathrm{T}$ cells in patients with neuroblastoma. Blood 118:6050-6056. https://doi.org/10.1182/blood -2011-05-354449

Mata M et al (2014) Toward immunotherapy with redirected T cells in a large animal model: ex vivo activation, expansion, and genetic modification of canine T cells. J Immunother 37:407-415. https ://doi.org/10.1097/CJI.0000000000000052

Mathew J, Perez EA (2011) Trastuzumab emtansine in human epidermal growth factor receptor 2-positive breast cancer: a review. Curr Opin Oncol 23:594-600. https://doi.org/10.1097/ CCO.0b013e32834b895c

Maude SL et al (2014) Chimeric antigen receptor T cells for sustained remissions in leukemia. N Engl J Med 371:1507-1517. https:// doi.org/10.1056/NEJMoa1407222

Meyer S, Leusen JH, Boross P (2014) Regulation of complement and modulation of its activity in monoclonal antibody therapy of cancer. MAbs 6:1133-1144. https://doi.org/10.4161/mabs.29670

Mitsuyasu RT et al (2000) Prolonged survival and tissue trafficking following adoptive transfer of CD4zeta gene-modified autologous CD4(+) and CD8(+) T cells in human immunodeficiency virus-infected subjects. Blood 96:785-793

Monjezi R et al (2017) Enhanced CAR T-cell engineering using nonviral Sleeping Beauty transposition from minicircle vectors. Leukemia 31:186-194. https://doi.org/10.1038/leu.2016.180

Moorkens E, Vulto AG, Huys I (2020) An overview of patents on therapeutic monoclonal antibodies in Europe: are they a hurdle to biosimilar market entry? MAbs 12:1743517. https://doi. org/10.1080/19420862.2020.1743517

Morgan RA, Yang JC, Kitano M, Dudley ME, Laurencot CM, Rosenberg SA (2010) Case report of a serious adverse event following the administration of $\mathrm{T}$ cells transduced with a chimeric antigen receptor recognizing ERBB2. Mol Ther 18:843-851. https://doi. org/10.1038/mt.2010.24

Nadler LM et al (1980) Serotherapy of a patient with a monoclonal antibody directed against a human lymphoma-associated antigen. Cancer Res 40:3147-3154

Nagy P, Friedlander E, Tanner M, Kapanen AI, Carraway KL, Isola J, Jovin TM (2005) Decreased accessibility and lack of activation of ErbB2 in JIMT-1, a herceptin-resistant, MUC4-expressing breast cancer cell line. Cancer Res 65:473-482

Nakajima M, Sakoda Y, Adachi K, Nagano H, Tamada K (2019) Improved survival of chimeric antigen receptor-engineered $\mathrm{T}$ (CAR-T) and tumor-specific $\mathrm{T}$ cells caused by anti-programmed cell death protein 1 single-chain variable fragmentproducing CAR-T cells. Cancer Sci 110:3079-3088. https://doi. org/10.1111/cas.14169

Neelapu SS et al (2017) Axicabtagene ciloleucel CAR T-cell therapy in refractory large B-cell lymphoma. N Engl J Med 377:2531-2544. https://doi.org/10.1056/NEJMoa1707447

Neelapu SS et al (2018) Chimeric antigen receptor T-cell therapy assessment and management of toxicities. Nat Rev Clin Oncol 15:47-62. https://doi.org/10.1038/nrclinonc.2017.148

Nesic D et al (2020) Cryo-electron microscopy Structure of the alphaIIbbeta3-abciximab complex arterioscler thromb. Vasc Biol 40:624-637. https://doi.org/10.1161/ATVBAHA.119.313671

O'Leary MC et al (2019) FDA approval summary: tisagenlecleucel for treatment of patients with relapsed or refractory B-cell precursor acute lymphoblastic leukemia. Clin Cancer Res 25:1142-1146. https://doi.org/10.1158/1078-0432.CCR-18-2035

Oppermans N, Kueberuwa G, Hawkins RE, Bridgeman JS (2020) Transgenic T-cell receptor immunotherapy for cancer: building on clinical success. Ther Adv Vaccines Immunother 8:2515135520933509. https://doi.org/10.1177/2515135520 933509 
Palyi-Krekk Z, Barok M, Isola J, Tammi M, Szollosi J, Nagy P (2007) Hyaluronan-induced masking of ErbB2 and CD44-enhanced trastuzumab internalisation in trastuzumab resistant breast cancer. Eur J Cancer 43:2423-2433. https://doi.org/10.1016/j. ejca.2007.08.018

Palyi-Krekk Z, Barok M, Kovacs T, Saya H, Nagano O, Szollosi J, Nagy P (2008) EGFR and ErbB2 are functionally coupled to CD44 and regulate shedding, internalization and motogenic effect of CD44. Cancer Lett 263:231-242. https://doi. org/10.1016/j.canlet.2008.01.014

Perlmann P, Perlmann H, Muller-Eberhard HJ (1975) Cytolytic lymphocytic cells with complement receptor in human blood. Induction of cytolysis by IgG antibody but not by target cell-bound C3. J Exp Med 141:287-296. https://doi.org/10.1084/jem.141.2.287

Porter CE et al (2020) Oncolytic adenovirus armed with BiTE, cytokine, and checkpoint inhibitor enables CAR T cells to control the growth of heterogeneous tumors. Mol Ther 28:1251-1262. https://doi.org/10.1016/j.ymthe.2020.02.016

Porter DL, Levine BL, Kalos M, Bagg A, June CH (2011) Chimeric antigen receptor-modified $\mathrm{T}$ cells in chronic lymphoid leukemia. N Engl J Med 365:725-733. https://doi.org/10.1056/NEJMo a1 103849

Ritchie DS et al (2013) Persistence and efficacy of second generation CAR T cell against the LeY antigen in acute myeloid leukemia. Mol Ther 21:2122-2129. https://doi.org/10.1038/mt.2013.154

Rivera AM, May S, Lei M, Qualls S, Bushey K, Rubin DB, Barra ME (2020) CAR T-cell-associated neurotoxicity: current management and emerging treatment strategies. Crit Care Nurs Q 43:191-204. https://doi.org/10.1097/CNQ.0000000000000302

Robert C et al (2014) Anti-programmed-death-receptor-1 treatment with pembrolizumab in ipilimumab-refractory advanced melanoma: a randomised dose-comparison cohort of a phase 1 trial. Lancet 384:1109-1117. https://doi.org/10.1016/S0140 $-6736(14) 60958-2$

Rosenberg SA (2014) IL-2: the first effective immunotherapy for human cancer. J Immunol 192:5451-5458. https://doi. org/10.4049/jimmunol.1490019

Rosenberg SA, Restifo NP, Yang JC, Morgan RA, Dudley ME (2008) Adoptive cell transfer: a clinical path to effective cancer immunotherapy. Nat Rev Cancer 8:299-308. https://doi.org/10.1038/ nrc2355

Roszik J et al (2011) T-cell synapse formation depends on antigen recognition but not CD3 interaction: studies with TCR:zeta, a candidate transgene for TCR gene therapy. Eur J Immunol 41:1288-1297. https://doi.org/10.1002/eji.200940233

Scaltriti M et al (2009) Lapatinib, a HER2 tyrosine kinase inhibitor, induces stabilization and accumulation of HER2 and potentiates trastuzumab-dependent cell cytotoxicity. Oncogene 28:803-814. https://doi.org/10.1038/onc.2008.432

Schmidt E, Hunzelmann N, Zillikens D, Brocker EB, Goebeler M (2006) Rituximab in refractory autoimmune bullous diseases. Clin Exp Dermatol 31:503-508. https://doi.org/10.111 1/j.1365-2230.2006.02151.x

Schubert ML et al (2020) Feasibility and safety of CD19 chimeric antigen receptor $\mathrm{T}$ cell treatment for $\mathrm{B}$ cell lymphoma relapse after allogeneic hematopoietic stem cell transplantation. Biol Blood Marrow Transplant 26:1575-1580. https://doi.org/10.1016/j. bbmt.2020.04.025

Servais EL et al (2012) Mesothelin overexpression promotes mesothelioma cell invasion and MMP-9 secretion in an orthotopic mouse model and in epithelioid pleural mesothelioma patients. Clin Cancer Res 18:2478-2489. https://doi.org/10.1158/10780432.CCR-11-2614

Smith TT et al (2017) situ programming of leukaemia-specific T cells using synthetic DNA nanocarriers. Nat Nanotechnol 12:813-820. https://doi.org/10.1038/nnano.2017.57
Steinman L (1990) The use of monoclonal antibodies for treatment of autoimmune disease. J Clin Immunol 10:30S-38S; discussion 38S-39S. https://doi.org/10.1007/BF00918689

Szoor A, Toth G, Zsebik B, Szabo V, Eshhar Z, Abken H, Vereb G (2020) Trastuzumab derived HER2-specific CARs for the treatment of trastuzumab-resistant breast cancer: CAR T cells penetrate and eradicate tumors that are not accessible to antibodies. Cancer Lett 484:1-8. https://doi.org/10.1016/j.canle t.2020.04.008

Tang J, Yu JX, Hubbard-Lucey VM, Neftelinov ST, Hodge JP, Lin Y (2018) Trial watch: the clinical trial landscape for PD1/PDL1 immune checkpoint inhibitors. Nat Rev Drug Discov 17:854 855. https://doi.org/10.1038/nrd.2018.210

Tang XY et al (2016) Third-generation CD28/4-1BB chimeric antigen receptor $\mathrm{T}$ cells for chemotherapy relapsed or refractory acute lymphoblastic leukaemia: a non-randomised, open-label phase I trial protocol. BMJ Open 6:e013904. https://doi.org/10.1136/ bmjopen-2016-013904

Tawara I et al (2017) Safety and persistence of WT1-specific T-cell receptor gene-transduced lymphocytes in patients with AML and MDS. Blood 130:1985-1994. https://doi.org/10.1182/blood -2017-06-791202

Tendeiro Rego R, Morris EC, Lowdell MW (2019) T-cell receptor gene-modified cells: past promises, present methodologies and future challenges. Cytotherapy 21:341-357. https://doi. org/10.1016/j.jcyt.2018.12.002

Toth G, Szollosi J, Abken H, Vereb G, Szoor A (2020) A small number of HER2 redirected CAR T cells significantly improves immune response of adoptively transferred mouse lymphocytes against human breast cancer xenografts. Int J Mol Sci. https:// doi.org/10.3390/ijms21031039

Toth G, Szoor A, Simon L, Yarden Y, Szollosi J, Vereb G (2016) The combination of trastuzumab and pertuzumab administered at approved doses may delay development of trastuzumab resistance by additively enhancing antibody-dependent cell-mediated cytotoxicity. MAbs 8:1361-1370. https://doi.org/10.1080/19420 862.2016.1204503

Tsumoto K, Isozaki Y, Yagami H, Tomita M (2019) Future perspectives of therapeutic monoclonal antibodies. Immunotherapy 11:119127. https://doi.org/10.2217/imt-2018-0130

van Vollenhoven RF et al (2013) Long-term safety of rituximab in rheumatoid arthritis: 9.5-year follow-up of the global clinical trial programme with a focus on adverse events of interest in RA patients. Ann Rheum Dis 72:1496-1502. https://doi.org/10.1136/ annrheumdis-2012-201956

Varadi T et al. (2012) Binding of trastuzumab to ErbB2 is inhibited by a high pericellular density of hyaluronan J Histochem Cytochem 60:567-575 doi:https://doi.org/10.1369/0022155412448070

Walseng E et al (2017) A TCR-based chimeric antigen receptor. Sci Rep 7:10713. https://doi.org/10.1038/s41598-017-11126-y

Wang QS et al (2015) Treatment of CD33-directed chimeric antigen receptor-modified $\mathrm{T}$ cells in one patient with relapsed and refractory acute myeloid leukemia. Mol Ther 23:184-191. https://doi. org/10.1038/mt.2014.164

Wang Y, Liu Y, Du Y, Yin W, Lu J (2013) The predictive role of phosphatase and tensin homolog (PTEN) loss, phosphoinositol-3 (PI3) kinase (PIK3CA) mutation, and PI3K pathway activation in sensitivity to trastuzumab in HER2-positive breast cancer: a meta-analysis. Curr Med Res Opin 29:633-642. https://doi. org/10.1185/03007995.2013.794775

$\mathrm{Xu}$ JY et al (2017) Mesothelin-targeting chimeric antigen receptor-modified $\mathrm{T}$ cells by piggyBac transposon system suppress the growth of bile duct carcinoma. Tumour Biol 39:1010428317695949. https://doi.org/10.1177/1010428317695949

Younes A, Bartlett NL, Leonard JP, Kennedy DA, Lynch CM, Sievers EL, Forero-Torres A (2010) Brentuximab vedotin (SGN-35) for 
relapsed CD30-positive lymphomas. N Engl J Med 363:18121821. https://doi.org/10.1056/NEJMoa1002965

Zhong XS, Matsushita M, Plotkin J, Riviere I, Sadelain M (2010) Chimeric antigen receptors combining 4-1BB and CD28 signaling domains augment PI3kinase/AKT/Bcl-XL activation and CD8+
T cell-mediated tumor eradication. Mol Ther 18:413-420. https ://doi.org/10.1038/mt.2009.210

Zhou G, Levitsky H (2012) Towards curative cancer immunotherapy: overcoming posttherapy tumor escape Clinical \& developmental immunology 2012:124187. https://doi.org/10.1155/2012/124187 